\title{
Isolation of Anti-Escherichia coli 0157:H7 Bacteriophages and Determination of Their Host Ranges
}

\author{
Zeliha Yıldırım*, Tuba Sakin, Fatma Çoban
}

Department of Food Engineering, Faculty of Engineering, Niğde Ömer Halisdemir University, 60250 Niğde, Turkey

\section{A R T I C L E I N F O}

\section{Research Article}

Received 04 May 2018

Accepted 12 July 2018

Keywords:

Escherichia coli $0157: \mathrm{H7}$

Bacteriophage

Isolation

Host range

Biocontrol

*Corresponding Author:

E-mail: zeliha.yildirim@ohu.edu.tr

A B S T R A C T

The aim of this study was to isolate, purify and determine host ranges of bacteriophages infecting Escherichia coli 0157:H7 from different environment such as river/stream water, sewage, raw food, animal troughs, wastewaters of food processing plants, slaughterhouse and fish farms. For screening of E. coli 0157:H7 bacteriophages, 92 samples were used. It was found that in respect to anti-E. coli O157:H7 bacteriophages, food processing wastewaters, sewage and slaughterhouse wastewaters are the richest sources, and streams, troughs and fisheries wastewater are rich in the middle, and raw foods were the poorest source. A total of 37 phages were isolated and purified. The phages counts of the purified samples were changed among $30 \times 10^{3}-34 \times 10^{8} \mathrm{PFU} / \mathrm{mL}$. The isolated phages were generally infective against $E$. coli $\mathrm{O} 157: \mathrm{H} 7$ and $E$. coli strains and $81.08 \%$ of the phages (30 out of 37 ) formed clear plaques and were capable to lyse at least 1 out of $5 \mathrm{E}$. coli O157:H7 strains. In addition to $E$. coli, some phages were capable to infect some Salmonella enterica serovars. This results show that inhibitor spectra of the phages were wide.

DOI: https://doi.org/10.24925/turjaf.v6i9.1200-1208.2000

\section{Introduction}

Escherichia coli belongs to the family Enterobacteriaceae, and is a Gram-negative, rod-shaped, motile, nonsporulating and facultative anaerobic bacterium. A majority of $E$. coli strains are nonpathogenic and exist harmlessly in the intestinal tract of humans and warm-blooded animals. They are routinely shed into the environment through feces and can contaminate water and soil, and, consequently fruits and vegetables (Bhunia, 2007; Ray, 2005).

Taxonomy of E. coli strains is based on specific virulence factors and phenotypic characters. Pathogenic E. coli strains are classified in six virotypes: enteroheamorraghic E. coli (EHEC), enterotoxigenic $E$. coli (ETEC), enteroinvasive $E$. coli (EIEC), enteroaggregative $E$. coli (EAEC) and diffusely adherent E. coli (DAEC). However, foodborne outbreaks have been particularly associated with EHEC and EAEC strains. EHEC or Shiga toxin-producing E. coli (STEC) strains that produce verocytotoxin or shiga-like toxin, the causative agent of diarrhea, heamorraghic colitis, haemolytic-ureamic syndrome and thrombotic thrombocytopenic purpura. Among the EHEC strains, E. coli $\mathrm{O} 157: \mathrm{H} 7$ has been widely recognized as the major cause of foodborne illness (Tarr et al., 2005; Wu et al.,
2011). The outbreaks of E. coli 0157:H7 have been linked to contaminated meat, meat products, unpasteurized milk and leafy green vegetables, radish sprouts and fruits fertilized with contaminated animal manure was the source of contamination (Sartz et al., 2008; CDC, 2011).

Bacteriophages (phages) are viruses that only infect and lyse specific bacterial hosts and do not infect human, animal or plant cells. Also, they generally do not cross bacterial species and consequently do not affect desirable microflora present in food (Carlton et al., 2005). Furthermore, the use of phages to control pathogenic bacteria has attracted considerable interest in recent years due to the emergence of antibiotic resistant foodborne pathogenic bacteria. In fact, early in this century, phages were used to treat bacterial infections before the advent of antibiotics. Virulent phages may provide a natural, nontoxic, feasible approach for controlling human foodborne pathogens (FDA, 2006; Hagens and Loessner, 2014; Tolba et al., 2014).

The aim of this study was to isolate phages infecting E. coli $\mathrm{O} 157: \mathrm{H} 7$ strains from environment and determine their host range and to have a collection of $E$. coli O157:H7 specific phages. 


\section{Materials and methods}

\section{Bacterial Strains and Culture Conditions}

E. coli $\mathrm{O} 157: \mathrm{H} 7$ strains used in phages screening were E. coli O157:H7 NCTC 12900, E. coli O157:H7 ATCC 43888, E. coli O157:H7 ATCC 35150, E. coli O157:H7 RSKK, E. coli 0157 AİBÜ. The strains were kept at $80^{\circ} \mathrm{C}$ in brain heart infusion broth (BHI, Merck, Darmstadt, Germany) with 20\% glycerol. Strains were obtained from our culture collection, culture collection of Biology Department of Ankara University and Veterinary Faculty of Kirıkkale University.

Collection and Preparation of Samples for Bacteriophage Screening

The samples used in bacteriophage screening were taken from river/stream water, sewage water, raw foods (milk, fruit, vegetable and meat), wastewater from food processing plants, slaughterhouse, and fish farms, and water from troughs found in Niğde, Aksaray, Ankara and Kayseri provinces. Water samples were centrifuged $(6.000 \times \mathrm{g}$ for $15 \mathrm{~min})$ and then the supernatants were passed through sterile cellulose nitrate membrane filter (0.45 and $0.22 \mu \mathrm{m})$ (Sartorius, Germany). Milk samples were centrifuged $(6.000 \times \mathrm{g}$ for $15 \mathrm{~min})$ after addition of lactic acid $(10 \%)$ to precipitate casein and then the supernatants were filtered sterilized $(0.45 \mu \mathrm{m}$ pore size $)$. Other semi hard and solid food samples (about $25 \mathrm{~g}$ ) were put in sterile stomacher bags and at that time $100 \mathrm{~mL}$ of SM buffer (50 mM Tris-Cl, pH 7.5, $99 \mathrm{mM} \mathrm{NaCl,} 8 \mathrm{mM}$ $\mathrm{MgSO}_{4}, \quad 0.01 \%$ gelatin) were added. After homogenization in a stomacher for $2 \mathrm{~min}$, the samples were centrifuged and the filtrate was passed through a $0.45 \mu \mathrm{m}$ sterile membrane filter. All filtrate samples gotten from water and food samples were used for bacteriophages isolation. A total of 92 samples were analyzed.

\section{Bacteriophages Isolation}

For isolation of bacteriophages, direct isolation and enrichment method were used. In the direct isolation method, filtered supernatants were directly used for bacteriophage screening against the test bacteria by the double agar layer plate method (Adams, 1959). In the enrichment protocol, $20 \mathrm{~mL}$ of the filtered samples were separately inoculated with $2 \mathrm{~mL}$ of actively grown culture of $E$. coli O157:H7 NCTC 12900, E. coli O157:H7 ATCC 43888, E. coli O157:H7 ATCC 35150, E. coli O157:H7 RSKK, E. coli O157:H7 AİBÜ in BHI broth and mixed with $3 \mathrm{~mL}$ of double strength BHI broth, and incubated at $35-37^{\circ} \mathrm{C}$ for 24 hours. Subsequently chloroform (50 $\mu \mathrm{L} / \mathrm{mL})$ was added into samples and vigorously mixed. After centrifugation $(5.000 \times \mathrm{g}$ for $15 \mathrm{~min})$, the supernatants were maintained at $5^{\circ} \mathrm{C}$. The samples were tested by spot and double agar layer plaque assay against individual E. coli O157:H7 strains (Mclaughlin et al., 2006).

Spot Testing and Double Layer Agar Plaque Assay

Spot testing was used to determine the presence of bacteriophage. The host bacterial lawn was made by using soft BHI top agar (0.7 \% agar) containing host bacterial suspensions and then overlaid on top of BHI agar $(1.5 \%$ agar) plates. When the agar overlays were solidified, the samples were spotted onto the lawns in plates. After incubation at $37^{\circ} \mathrm{C}$ for $24 \mathrm{~h}$, all plates were observed for the clear zone formation.

The double-layer agar plaque method was used to determine the titer of phage as follow (Adams, 1959). One hundred micro liter of a dilution of the membrane filtered phage samples and $300 \mu \mathrm{L}$ of the actively growing E. coli $\mathrm{O} 157: \mathrm{H} 7$ cultures (about $10^{8} \mathrm{CFU} / \mathrm{mL}$ ) were added into BHI soft agar $\left(0.7 \%\right.$ agar) at $45-50^{\circ} \mathrm{C}$. After mixing, the contents of the tube were immediately poured onto BHI basal agar $(1.5 \%)$ on Petri dishes and then the plates were incubated at $37^{\circ} \mathrm{C}$ for $24 \mathrm{~h}$. At the end of incubation, phage numbers were counted (PFU/mL).

\section{Purification of Bacteriophages}

Bacteriophages are purified by removing a well isolated plaque using the wide end of a sterile Pasteur pipette and the phages were eluted with shaking for a minimum of $2 \mathrm{~h}$ in $100 \mu \mathrm{L}$ SM buffer $(50 \mathrm{mM}$ Tris-Cl, pH 7.5, $99 \mathrm{mM} \mathrm{NaCl}, 8 \mathrm{mM} \mathrm{MgSO}_{4}, 0.01 \%$ gelatin). After chloroform $(50 \mu \mathrm{l} / \mathrm{mL})$ extraction and centrifugation $\left(9.000 \times \mathrm{g}, 20 \mathrm{~min}, 4^{\circ} \mathrm{C}\right)$, the supernatant was transferred to a new sterile tube. The prepared serial dilutions of the phage samples were inoculated into an early-log phase host culture, and the lysate was replated as described above. Bacteriophage purification process was repeated at least three times through plaque assay, reinfection, centrifugation and resuspension to ensure purity of the phage. To determine the number of phage in the each sample, the double layer agar method were used (Stenholm vd., 2008).

\section{Preparation of Phages Stocks}

To prepare high titer phage stocks, $1 \mathrm{~mL}$ of overnight E. coli $\mathrm{O} 157: \mathrm{H} 7$ cultures in $\mathrm{BHI}$ broth at $37^{\circ} \mathrm{C}$ and 100 $\mu \mathrm{L}$ of the purified phage stock were put into $100 \mathrm{~mL} \mathrm{BHI}$ broth and after mixing, they were incubated overnight at $37^{\circ} \mathrm{C}$. After addition of chloroform $(50 \mu \mathrm{L} / \mathrm{mL})$ to lyse the bacterial cells, the amplified phages were centrifuged $(9.000 \times \mathrm{g}$ for $13 \mathrm{~min})$ and the supernatants were filtered with a disposable 0.45 or $0.22 \mu \mathrm{m}$ pore size syringe membrane filter (Sartorius, Germany) (Kocharunchitt et al., 2009). The titre of the phage stock was determined by the double-layer plaque titration method (Adam, 1959).

\section{Investigation of Host Range of Bacteriophages}

Various species or strains or serovars of E. coli, Salmonella, Shigella, Yersenia, Citrobacter, Enterobacter, Listeria, Staphylococcus, Bacillus and Enterococcus was used to determine host ranges of antiE. coli $\mathrm{O} 157: \mathrm{H} 7$ bacteriophages (Table 1). To determine host ranges of bacteriophage samples, $300 \mu \mathrm{l}$ of logarithmic phase $\left(\mathrm{OD}_{600}=0.3\right)$ suspensions of host strains were put into BHI soft agar and then it was poured onto dried base plates. Subsequently, $10 \mu \mathrm{L}$ of the $10^{-2}, 10^{-4}$, $10^{-6}$ phage dilutions were spotted on the overlay. After incubation at $35-37^{\circ} \mathrm{C}$ for $24 \mathrm{~h}$, the plates were examined for plaque formation. 
Table 1 Bacteria used to isolate E. coli $\mathrm{O} 157: \mathrm{H} 7$ specific bacteriophages and to determine their host ranges

\begin{tabular}{l|ll}
\hline Escherichia coli O157:H7 NCTC 12900 & S. Typhimurium MET-S1-625 & S. Anatum DMC90 \\
E. coli O157:H7 ATCC 43888 & S. Typhimurium AIBU & S. Telaviv DMC62 \\
E. coli O157:H7 ATCC 35150 & S. Typhimurium ATCC 14028 & S. Montavide DMC81 \\
E. coli O157:H7 RSKK & S. Enteritidis DMC8 & S. Kentucky DMC35 \\
E. coli O157 AIBU & S. Enteritidis DMC22 & S. Carvalis DMC86 \\
E. coli DS $\alpha$ & S. Enteritidis ATCC 13075 & Listeria monocytogenes ATCC19115 \\
E. coli BL21 & S. Enteritidis MET-S1-411 & Staphylococcus aureus ATCC 25923 \\
E. coli CFAI & S. Enteritidis MET-S1-512 & Bacillus cereus ATCC 10875 \\
E. coli ATCC 25922 & S. Enteritidis MET-S1-742 & Yersinia enterocolitica O:9 AU \\
Salmonella Typhimurium LT2 SR II & Salmonella Virchow DMC8 & Citrobacter freundii AU \\
S. Typhimurium Tr90 & S. Infantis DMC7 & Enterobacter aerogenes AU \\
S. Typhimurium Wild type 14028 & S. Thompson DMC47 & Enterococcus faecalis ATCC 29212 \\
\hline
\end{tabular}

MET, Middle East Technical University; AIBU, Abant İzzet Baysal University; AU, Ankara University

\section{Results and Discussion}

Isolation of E. coli O157:H7 Specific Bacteriophages

In the present study, E. coli O157:H7 specific bacteriophages which were lytic and broad spectrum were isolated from natural sources and purified and developed a collection of phages to biocontrol foodborne pathogenic E. coli $\mathrm{O} 157: \mathrm{H} 7$. A total of 92 samples were used for the screening of bacteriophages. Of the 92 samples, 12 were taken from river/stream water, 13 from sewage, 10 from waste water of fish farms, 18 from raw foods (milk, fruit, vegetable and meat), 11 from wastewater of food processing plants, 13 from wastewater of slaughterhouse, and 8 from water of troughs. The results of phage screening were given in Table 2.

Table 2 Isolated bacteriophages infecting E. coli O157:H7 serovars

\begin{tabular}{|c|c|c|c|}
\hline Sample & Name of phage & Host Serovar & Number of phage (PFU/mL) \\
\hline \multirow{3}{*}{ Rivers/streams } & Eco-Phage-1 & E. coli O157:H7 NCTC 12900 & $22.1 \times 10^{7}$ \\
\hline & Eco-Phage-2 & E. coli $\mathrm{O} 157: \mathrm{H} 7 \mathrm{RSKK}$ & $34.0 \times 10^{8}$ \\
\hline & Eco-Phage-3 & E. coli O157:H7 NCTC 12900 & $36.0 \times 10^{4}$ \\
\hline \multirow{10}{*}{ Sewage } & Eco-Phage-4 & E. coli O157:H7 RSKK & $44.0 \times 10^{8}$ \\
\hline & Eco-Phage-5 & E. coli O157:H7 NCTC 12900 & $31.5 \times 10^{6}$ \\
\hline & Eco-Phage- 6 & E. coli $\mathrm{O} 157: \mathrm{H} 7$ ATTC 43888 & $47.0 \times 10^{7}$ \\
\hline & Eco-Phage-7 & E. coli $\mathrm{O} 157: \mathrm{H} 7 \mathrm{RSKK}$ & $52.5 \times 10^{5}$ \\
\hline & Eco-Phage-8 & E. coli $\mathrm{O} 157: \mathrm{H} 7$ ATTC 35150 & $80.0 \times 10^{6}$ \\
\hline & Eco-Phage-9 & E. coli $\mathrm{O} 157: \mathrm{H} 7 \mathrm{RSKK}$ & $80.0 \times 10^{6}$ \\
\hline & Eco-Phage-10 & E. coli $\mathrm{O} 157: \mathrm{H} 7$ AİBÜ & $12.2 \times 10^{6}$ \\
\hline & Eco-Phage-11 & E. coli $\mathrm{O} 157: \mathrm{H} 7$ ATTC 35150 & $15.0 \times 10^{7}$ \\
\hline & Eco-Phage-12 & E. coli $\mathrm{O} 157: \mathrm{H} 7 \mathrm{NCTC} 12900$ & $21.0 \times 10^{4}$ \\
\hline & Eco-Phage-13 & E. coli $\mathrm{O} 157: \mathrm{H} 7$ ATTC 43888 & $34.5 \times 10^{4}$ \\
\hline \multirow{2}{*}{ Fisheries wastewater } & Eco-Phage-14 & E. coli $\mathrm{O} 157: \mathrm{H} 7 \mathrm{RSKK}$ & $16.0 \times 10^{7}$ \\
\hline & Eco-Phage-15 & E. coli $\mathrm{O} 157: \mathrm{H} 7 \mathrm{RSKK}$ & $70.0 \times 10^{5}$ \\
\hline \multirow{12}{*}{$\begin{array}{l}\text { Food processing } \\
\text { wastewater }\end{array}$} & Eco-Phage-16 & E. coli O157:H7 ATTC 35150 & $38.5 \times 10^{4}$ \\
\hline & Eco-Phage-17 & E. coli $\mathrm{O} 157: \mathrm{H} 7 \mathrm{RSKK}$ & $24.0 \times 10^{7}$ \\
\hline & Eco-Phage-18 & E. coli $\mathrm{O} 157: \mathrm{H} 7$ ATTC 35150 & $12.1 \times 10^{7}$ \\
\hline & Eco-Phage-19 & E. coli $\mathrm{O} 157: \mathrm{H} 7 \mathrm{NCTC} 12900$ & $28.5 \times 10^{7}$ \\
\hline & Eco-Phage-20 & E. coli $\mathrm{O} 157: \mathrm{H} 7 \mathrm{RSKK}$ & $72.0 \times 10^{6}$ \\
\hline & Eco-Phage-21 & E. coli $\mathrm{O} 157: \mathrm{H} 7$ ATTC 35150 & $22.0 \times 10^{5}$ \\
\hline & Eco-Phage-22 & E. coli O157:H7 NCTC 12900 & $61.0 \times 10^{6}$ \\
\hline & Eco-Phage-23 & E. coli $\mathrm{O} 157: \mathrm{H} 7$ ATTC 43888 & $23.2 \times 10^{7}$ \\
\hline & Eco-Phage-24 & E. coli $\mathrm{O} 157: \mathrm{H} 7 \mathrm{NCTC} 12900$ & $89.0 \times 10^{6}$ \\
\hline & Eco-Phage-25 & E. coli $\mathrm{O} 157: \mathrm{H} 7 \mathrm{RSKK}$ & $30.0 \times 10^{8}$ \\
\hline & Eco-Phage-26 & E. coli $\mathrm{O} 157: \mathrm{H} 7$ ATTC 43888 & $82.0 \times 10^{5}$ \\
\hline & Eco-Phage-27 & E. coli $\mathrm{O} 157: \mathrm{H} 7$ AİBÜ & $49.0 \times 10^{5}$ \\
\hline \multirow{7}{*}{$\begin{array}{l}\text { Slaughterhouse } \\
\text { wastewater }\end{array}$} & Eco-Phage-28 & E. coli $\mathrm{O} 157: \mathrm{H} 7 \mathrm{RSKK}$ & $37.5 \times 10^{5}$ \\
\hline & Eco-Phage-29 & E. coli $\mathrm{O} 157: \mathrm{H7}$ AİBÜ & $30.0 \times 10^{3}$ \\
\hline & Eco-Phage-30 & E. coli $\mathrm{O} 157: \mathrm{H} 7 \mathrm{RSKK}$ & $54.0 \times 10^{5}$ \\
\hline & Eco-Phage-31 & E. coli $\mathrm{O} 157: \mathrm{H} 7$ AİBÜ & $12.4 \times 10^{6}$ \\
\hline & Eco-Phage-32 & E. coli $\mathrm{O} 157: \mathrm{H} 7$ ATTC 35150 & $28.0 \times 10^{5}$ \\
\hline & Eco-Phage-33 & E. coli $\mathrm{O} 157: \mathrm{H} 7$ AİBÜ & $37.0 \times 10^{5}$ \\
\hline & Eco-Phage-34 & E. coli $\mathrm{O} 157: \mathrm{H} 7 \mathrm{RSKK}$ & $66.0 \times 0^{5}$ \\
\hline \multirow{3}{*}{ Trough } & Eco-Phage-35 & E. coli $\mathrm{O} 157: \mathrm{H} 7 \mathrm{RSKK}$ & $24.0 \times 10^{5}$ \\
\hline & Eco-Phage-36 & E. coli $\mathrm{O} 157: \mathrm{H} 7$ AİBÜ & $13.0 \times 10^{4}$ \\
\hline & Eco-Phage-37 & E. coli $\mathrm{O} 157: \mathrm{H} 7$ ATTC 43888 & $37.5 \times 10^{7}$ \\
\hline
\end{tabular}


As seen Table 2, food processing waste waters, sewage and slaughterhouse wastewaters are the richest sources in respect to anti-E. coli $\mathrm{O} 157: \mathrm{H} 7$ bacteriophages. Conversely, streams, troughs and fisheries waste water were found to be quite poor. In addition, E. coli $\mathrm{O} 157: \mathrm{H} 7$ bacteriophages were not detected in milk, meat, fruits and vegetables. Thirty seven E. coli O157:H7 specific bacteriophages were isolated. Some isolated phages were given in Fig. 1.

Many researchers reported that the presence of bacteriophages is strictly associated with their natural host bacterial cells. E. coli $\mathrm{O} 157: \mathrm{H} 7$ is a natural inhabitant of the gastrointestinal tract of animals and human, and abundant in feces. As a result, they are natural members of the microbial ecosystem and therefore they are easily transmitted to sewage, waste water, soil and food. Consequently, various waste effluents such as sewage, naturally provide the best source for isolation of phage infecting E. coli O157:H7 (Oot et al., 2007; Synnott et al.,
2009; Viazis et al., 2011). Similar to our results a number of researchers isolated phages specific for $E$. coli O157:H7 have previously been isolated from natural and their host environments (Kudva et al., 1999; Morita et al., 2002; Oot et al., 2007; Synnott et al., 2009; Niu et al. 2009b; Viazis et al., 2011; Raya et al., 2011; Litt and Jaroni, 2017).

It was found that for isolation of bacteriophages, the enrichment method was better than direct method since the number of phages in the samples examined by the enrichment process increased considerably compared to the direct method. This increase was especially pronounced in case where the count of phages was low (e.g. river/stream waters) (Fig. 2). Some researchers also reported that the phage titer of the sample isolated were increased by using enrichment method (Mclaughlin et al., 2006; Oot et al. 2007; Viazis et al. 2011; Akhtar et al., 2014).
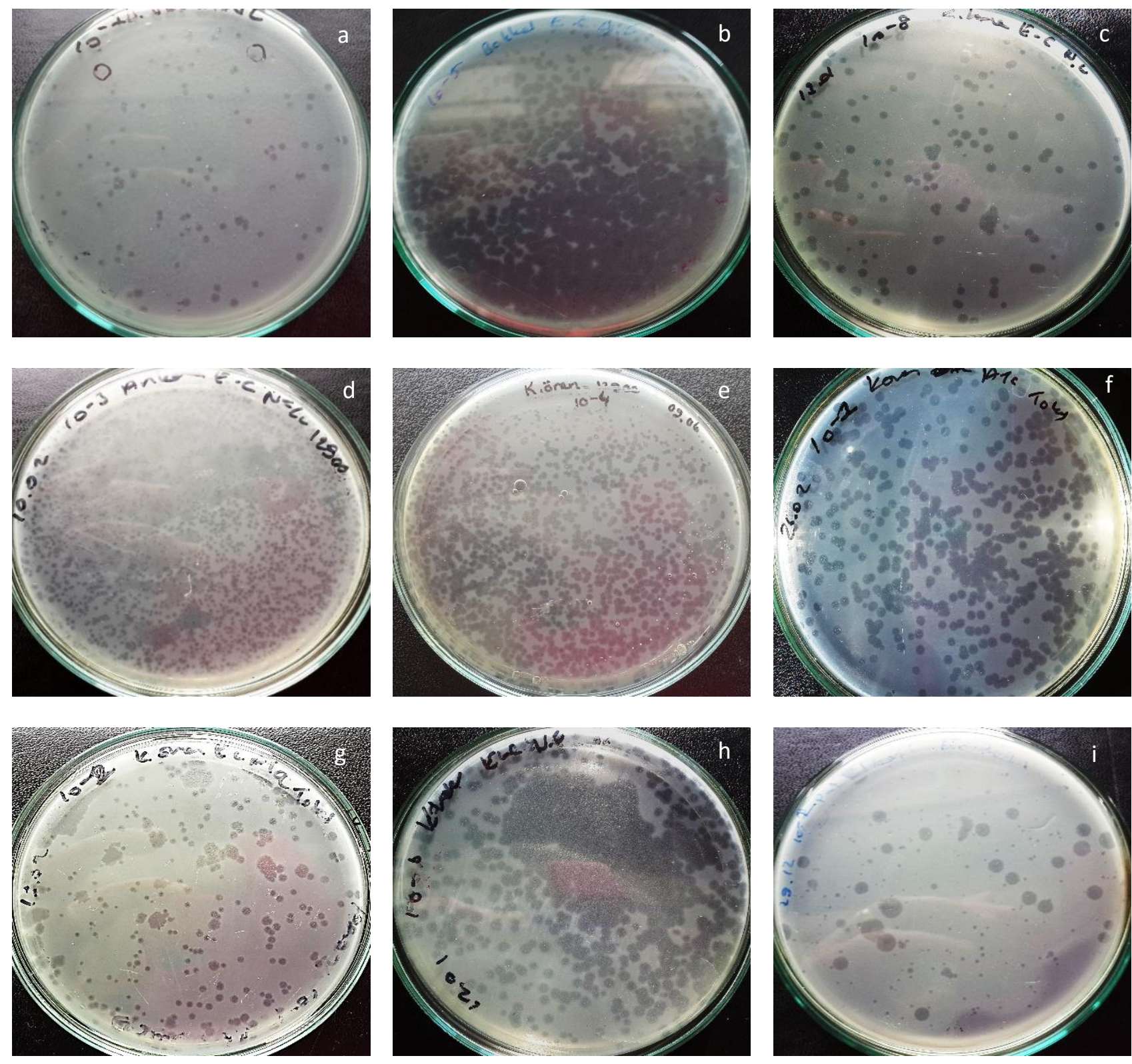

Fig 1 Some of isolated E. coli O157:H7 specific bacteriophages. Bacteriophage from food processing wastewaters (a), (b) and (c); bacteriophages from sewages (d), (e) and (f); bacteriophages from slaughterhouse wastewaters (g), (h) and (i). 

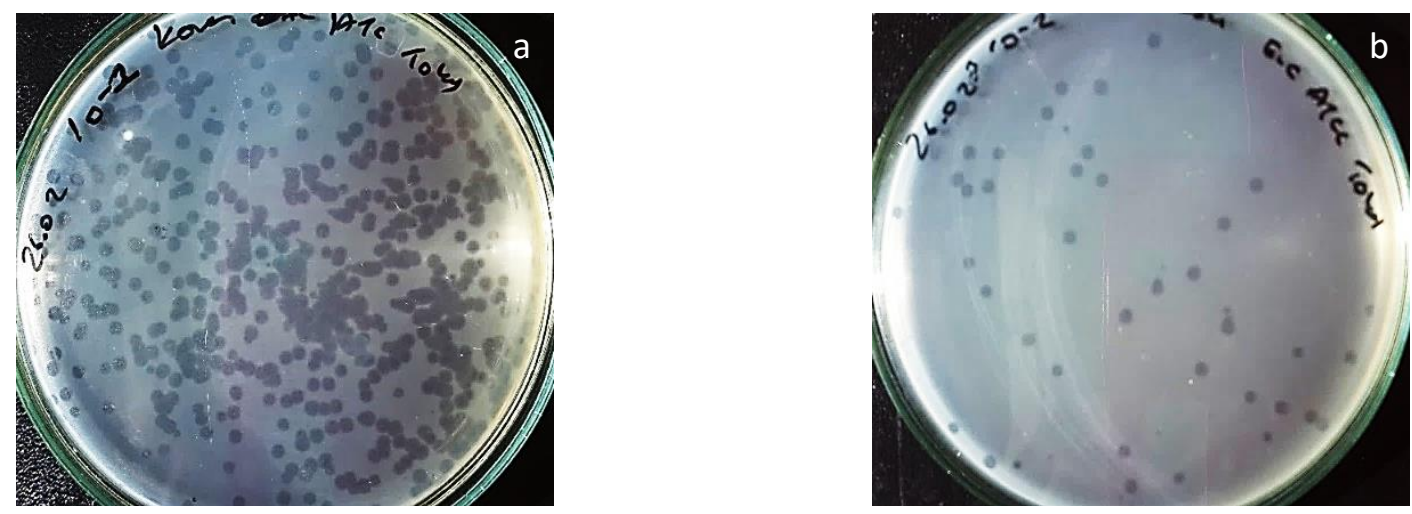

Fig. 2 Comparison of enrichment method (a) versus direct (b)
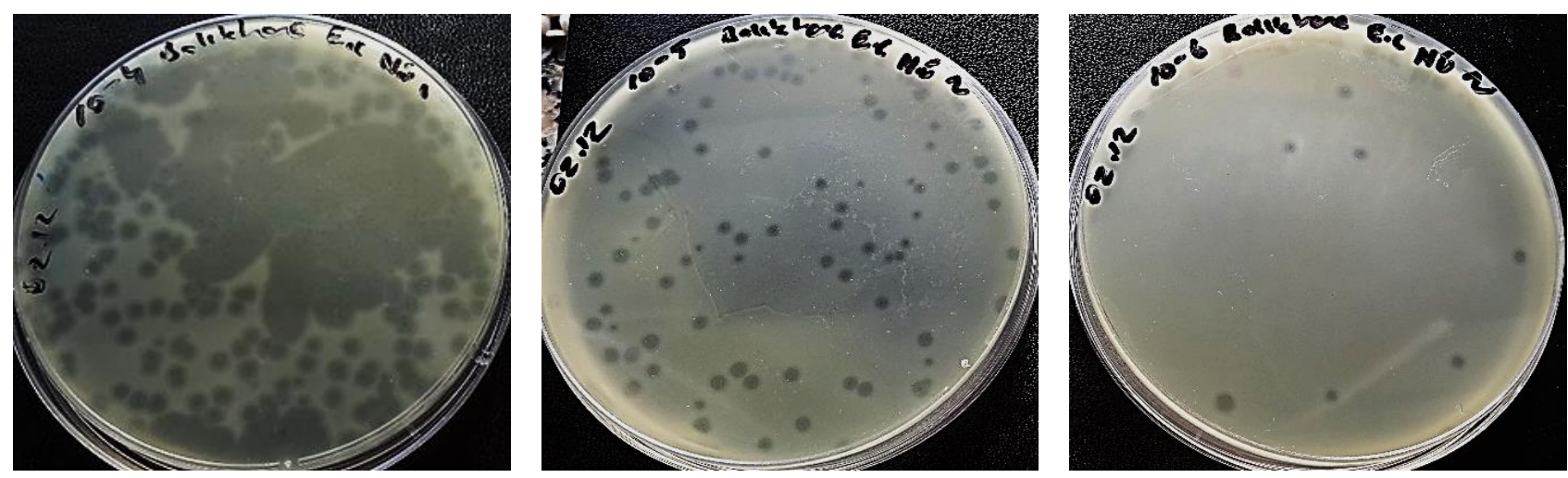

Fig. 3 Purification of E. coli O157:H7 bacteriophages Stocks

Purification of Phage and Preparation of Phage

A single plaque method was used to purify isolated phages (Adam, 1958). In purification procedure, a single plaque was taken from Petri plate containing maximum of 4-5 phage plaques and this process was repeated at least 3 times (Fig. 3). The purified bacteriophages were stored at $-80^{\circ} \mathrm{C}$ in SM buffer with $20 \%$ glycerol. It was determined that the bacteriophage titer of the sample stocks were between $30 \times 10^{3}-44 \times 10^{8} \mathrm{PFU} / \mathrm{mL}$. The isolation environment of 37 purified phages and their naming was summarized in Table 2.

\section{Host Ranges of Bacteriophages}

To examine their host ranges, the isolated $E$. coli O157:H7 phages were tested against 5 different $E$. coli O157:H7 strains, 4 other $E$. coli strains, $6 S$. Typhimurium, $6 \mathrm{~S}$. Enteritidis serovars, 8 other Salmonella enterica serovars, and 7 different Gramnegative and Gram-positive species (Table 3 and 4). All 37 isolated anti-E. coli $\mathrm{O} 157: \mathrm{H} 7$ phages were capable of lysing their host strains throughout the purification procedure and they were generally infective against $E$. coli $\mathrm{O} 157: \mathrm{H} 7$ and $E$. coli strains. $81.08 \%$ of isolated phages (30 out of 37) formed clear plaques and were capable to lyse at least 1 out of 5 E. coli $\mathrm{O} 157: \mathrm{H} 7$ strains. It was observed that $18.92 \%$ of the phages (Eco-phage 2, $10,14,20,28,35$ and 36) were lysogenic and did not form clear zone against their host cells. The isolated phages were able to lyse minimum 1 to maximum 8 of 36 strains tested with highly variable host ranges. Host ranges of some phages, Eco-Phage-7, 11, 13, 17, 21, 23, 2430,34 and 35 were wide and effective against 4 to 8 strains tested, but the remaining phages have narrow inhibitory spectrum, being just able to 1 to 3 strains tested (Table 3). Eco-phage-13, 17, 24 and 34 lysed $80 \%$ of the E. coli $\mathrm{O} 157: \mathrm{H} 7$ (4 out of 5 different strains) and 12 Ecophage were able to lyse $60 \%$ of the E. coli $\mathrm{O} 157: \mathrm{H} 7$ strains tested (3 out of 5 different strains) (Table 3 ).

It was observed that $E$. coli $\mathrm{O} 157: \mathrm{H} 7$ specific phages do not have strain specificity. The isolated total 37 phages were infective against at least one of the E. coli O157:H7 strains tested and 14 of 37 Eco-phages were highly infective against strains of E. coli O157:H7 NTCT 12900, ATTC 4388 and ATCC 35150 strains. Furthermore, 15 out of 37 Eco-phages $(40.54 \%)$ were infective against other E. coli strains tested besides E. coli $\mathrm{O} 157: \mathrm{H} 7$ strains (Table 3).

Double layer agar testing against 20 strains of different serovars of Salmonella was used to investigate the cross-species infectivity of each phage. Phage lysis of Salmonella ranged from 0 to $50 \%$ of the 20 strains tested (Table 3 and 4). Eco-phage-12 and 23 were effective against two different Salmonella Enteritidis strains (Table $3)$, Eco-phage-13 was effective against one Salmonella Typhimurium strain (Table 4), and Eco-phage-11, 13,17, $21,23,30$ and 34 effective against different other Salmonella enterica serovars (Table 4). None of the isolated Eco-phages were found to be infective against Listeria monocytogenes, Staphylococcus aureus, Bacillus cereus, Yersinia enterocolitica, Citrobacter freundii, Enterobacter aerogenes and Enterococcus faecalis. 
Table 3 Host ranges of E. coli O157:H7 specific phages on E. coli strains and Salmonella Enteritidis

\begin{tabular}{|c|c|c|c|c|c|c|c|c|c|c|c|c|c|c|c|}
\hline \multirow{2}{*}{ EP } & \multicolumn{5}{|c|}{ E. coli $\mathrm{O} 157: \mathrm{H} 7$} & \multicolumn{4}{|c|}{ E. coli } & \multicolumn{6}{|c|}{ Salmonella Enteritidis } \\
\hline & 12900 & 43888 & 35150 & AİBய̈ & RSKK & $\mathrm{DS} \alpha$ & BL21 & CFAI & 25922 & DMC8 & DMC22 & 13075 & 411 & 512 & 742 \\
\hline 1 & +++ & +++ & ++- & - & - & - & - & - & - & - & - & - & - & - & - \\
\hline 2 & - & - & - & - & +++ & - & - & - & - & - & - & - & - & - & - \\
\hline 3 & +++ & +++ & +++ & - & - & - & - & - & - & - & - & - & - & - & - \\
\hline 4 & - & - & +++ & - & +++ & - & - & - & - & - & - & - & - & - & - \\
\hline 5 & +++ & - & - & - & - & - & - & - & - & - & - & - & - & - & - \\
\hline 6 & +++ & +++ & - & - & - & - & - & - & +++ & - & - & - & - & - & - \\
\hline 7 & +++ & - & - & - & +++ & +++ & ++- & ++- & - & - & - & - & - & - & - \\
\hline 8 & - & - & +++ & - & - & - & - & - & - & - & - & - & - & - & - \\
\hline 9 & - & - & - & - & +++ & - & - & - & - & - & - & - & - & - & - \\
\hline 10 & - & - & - & +++ & - & - & - & - & - & - & - & - & - & - & - \\
\hline 11 & +++ & ++- & +++ & - & - & - & - & - & - & - & - & - & - & - & - \\
\hline 12 & +++ & +++ & +++ & - & - & - & - & - & - & - & - & - & - & - & - \\
\hline 13 & +++ & +++ & +++ & +++ & - & - & - & - & - & - & - & - & ++- & - & - \\
\hline 14 & - & - & - & - & +++ & - & - & +-- & - & - & - & - & - & - & - \\
\hline 15 & - & - & - & - & +++ & - & - & - & - & - & - & - & - & - & - \\
\hline 16 & +++ & +++ & +++ & - & - & - & - & - & - & - & - & - & - & - & - \\
\hline 17 & ++- & +-- & ++- & - & +++ & - & - & - & +++ & - & - & - & - & - & - \\
\hline 18 & - & - & +++ & - & - & - & - & - & - & - & - & - & - & - & - \\
\hline 19 & +++ & +++ & +++ & - & - & - & - & - & - & - & - & - & - & - & - \\
\hline 20 & - & - & - & - & +++ & - & - & - & - & - & - & - & - & - & - \\
\hline 21 & ++- & +++ & +++ & - & - & - & - & - & - & - & - & - & - & - & - \\
\hline 22 & +++ & +++ & +++ & - & - & - & - & - & - & - & - & - & - & - & - \\
\hline 23 & +++ & +++ & +-- & - & - & - & - & - & +++ & ++-- & - & - & - & - & - \\
\hline 24 & +++ & +++ & +++ & - & +-- & - & - & - & - & - & - & - & - & - & - \\
\hline 25 & - & - & - & - & +++ & - & +-- & - & - & - & - & - & - & - & - \\
\hline 26 & +++ & +++ & +++ & - & - & - & - & - & - & - & - & - & - & - & - \\
\hline 27 & - & - & - & +++ & - & - & - & +++ & - & - & - & - & - & - & - \\
\hline 28 & - & - & - & - & +++ & - & - & - & +++ & - & - & - & - & - & - \\
\hline 29 & - & - & - & +++ & - & - & - & +++ & - & - & - & - & - & - & - \\
\hline 30 & - & - & - & - & +++ & +++ & - & - & ++- & - & - & - & - & - & - \\
\hline 31 & - & - & - & +++ & - & - & - & - & +++ & - & - & - & - & - & - \\
\hline 32 & - & - & +++ & - & - & - & - & +-- & ++-- & - & - & - & - & - & - \\
\hline 33 & - & - & - & +++ & - & - & - & - & - & - & - & - & - & - & - \\
\hline 34 & +++ & +++ & +++ & - & +++ & - & - & - & - & - & - & - & - & - & - \\
\hline 35 & - & - & - & - & +++ & +++ & - & +++ & +++ & - & - & - & - & - & - \\
\hline 36 & - & - & - & +++ & - & - & - & - & +++ & - & - & - & - & - & - \\
\hline 37 & +++ & +++ & - & - & - & - & - & - & ++- & - & - & - & - & - & - \\
\hline
\end{tabular}

EP: Eco-Phage, $+++, 10^{-2}, 10^{-4}$ and $10^{-6}$ diluted phage samples were inhibitor positive; ++-, $10^{-2}, 10^{-4}$ diluted phage samples were inhibitor positive but $10^{-6}$ dilution sample was inhibitor negative; +--, $10^{-2}$ dilution sample was inhibitor positive, $10^{-4}$ and $10^{-6}$ dilution sample was inhibitor negative; -, $10^{-2}, 10^{-4}$ and $10^{-6}$ diluted phage samples were inhibitor negative

Wide host range phages specific to E. coli O157:H7 strains with clear plaques were predominantly isolated from wastewater from food processing and slaughterhouse, sewage and troughs. Eco-phage-13 had the broadest host range, with lytic ability against 8 different bacterial strains (lysed $22.22 \%$ of the strains tested), 4 of them from E. coli O157:H7, 1 from Salmonella Enteritidis (Table 3), 1 from Salmonella Typhimurium, and 2 from other Salmonella serovars (Table 4). This was followed by Eco-phage-23, 7, 34, 11, and 21, being infective against 4 to 6 different bacterial strains (Table 3 and 4 ).

Host specificity is a common property of bacteriophages, but, it is a restrictive factor in their usage in food industry to prevent and/or inhibit the growth of foodborne pathogenic bacteria (Bielke et al., 2007). In our study, many isolated Eco-phages showed wide host ranges, being infective against at least 3 different $E$. coli O157:H7 strains tested.
Viazis et al. (2011) informed that lytic ability of 70 EHEC bacteriophages ranged from 5.3 to $31.6 \%$ and 8 out of 70 phages $(38,39,41$, AR1, 42, CEV2, ECB7 and ECA1) lysed from 94 to $98 \%$ of the E. coli $\mathrm{O} 157: \mathrm{H} 7$ strains screened using spot testing. The same researchers also determined the cross-genus activity of the EHEC phages against the 27 strains of different serovars of Salmonella and they found that phage ECB7 lysed $48.2 \%$ of the Salmonella strains, while the rest of the phage lysed from none to $22.2 \%$ of the strains of this pathogen. Villegas et al. (2009) reported that although the EHEC O157:H7-specific bacteriophage wV8 had genome characteristics very similar to the Salmonella specific phage Felix O1, it could not lyse any strains from 12 Salmonella serovars through spot testing.

Raya et al. (2006) reported that CEV1 phage was active against 17/19 E. coli $\mathrm{O} 157: \mathrm{H} 7$ strains tested, but not active 9 strains from $4 / 5$ phylogenetic groups of the $E$. coli reference (ECOR) collection, lab strains B and K-12, 
and strains from serogroups O43, O126, O153, O158, and Salmonella enterica serovars tested. Conversely, Ibrahim (1969) found that E. coli phages were also effective against some Salmonella serovars besides their host cells.

Some researchers reported that phages specific to one E. coli $\mathrm{O} 157: \mathrm{H} 7$ strain can also infect other $\mathrm{O} 157: \mathrm{H} 7$ strains (Bach et al., 2003; Litt and Jaroni, 2017; Raya et al., 2006; Sheng et al., 2006; Viazis et al. 2011). \$241 phage, specific for E. coli O157:H7, is O157 antigenspecific and therefore just only infect strains that have O157 antigen, and E. coli strains lacking $\mathrm{O} 157$ antigen were resistant to the phage infection, regardless of the presence or absence of $\mathrm{H} 7$ antigen (Lui and Breidth, 2015). Results from the present study are similar to these studies, revealing that isolated phages are virulent against other E. coli $\mathrm{O} 157: \mathrm{H} 7$ strains with high target specificity.

Table 4 Host ranges of E. coli O157:H7 specific phages on Salmonella Typhimurium and other Salmonella enterica serovars

\begin{tabular}{|c|c|c|c|c|c|c|c|c|c|c|c|c|c|c|}
\hline \multirow[b]{2}{*}{ EP } & \multicolumn{6}{|c|}{ Salmonella Typhimurium } & \multicolumn{8}{|c|}{ Other Salmonella enterica serovars } \\
\hline & $\begin{array}{l}\text { LT- } \\
\text { SRII }\end{array}$ & $\operatorname{Tr} 90$ & AİBÜ & $\begin{array}{l}\text { Wild } \\
\text { type }\end{array}$ & 625 & 14028 & $\begin{array}{c}\text { S. } \\
\text { Virchow } \\
\text { DMC8 }\end{array}$ & $\begin{array}{c}S . \\
\text { Infantis } \\
\text { DMC7 }\end{array}$ & $\begin{array}{c}S . \\
\text { Thompson } \\
\text { DMC47 }\end{array}$ & $\begin{array}{c}S . \\
\text { Anatum } \\
\text { DMC90 }\end{array}$ & $\begin{array}{c}S . \\
\text { Telaviv } \\
\text { DMC62 }\end{array}$ & $\begin{array}{c}S . \\
\text { Montavide } \\
\text { DMC81 }\end{array}$ & $\begin{array}{c}S . \\
\text { Kentucky } \\
\text { DMC35 }\end{array}$ & $\begin{array}{c}S . \\
\text { Carvalis } \\
\text { DMC86 }\end{array}$ \\
\hline 1 & - & - & - & - & - & - & - & - & - & - & - & - & - & - \\
\hline 2 & - & - & - & - & - & - & - & - & - & - & - & - & - & - \\
\hline 3 & - & - & - & - & - & - & - & - & - & - & - & - & - & - \\
\hline 4 & - & - & - & - & - & - & - & - & - & - & - & - & - & - \\
\hline 5 & - & - & - & - & - & - & - & - & - & - & - & - & - & - \\
\hline 6 & - & - & - & - & - & - & - & - & - & - & - & - & - & - \\
\hline 7 & - & - & - & - & - & - & - & - & - & - & - & - & - & - \\
\hline 8 & - & - & - & - & - & - & - & - & - & - & - & - & - & - \\
\hline 9 & - & - & - & - & - & - & - & - & - & - & - & - & - & - \\
\hline 10 & - & - & - & - & - & - & - & - & - & - & - & - & - & - \\
\hline 11 & - & - & - & - & - & - & - & - & - & - & - & - & +++ & - \\
\hline 12 & - & - & - & - & - & - & - & - & - & - & - & - & - & - \\
\hline 13 & - & - & - & - & - & ++- & - & - & - & ++- & - & - & ++- & - \\
\hline 14 & - & - & - & - & - & - & - & - & - & - & - & - & - & - \\
\hline 15 & - & - & - & - & - & - & - & - & - & - & - & - & - & - \\
\hline 16 & - & - & - & - & - & - & - & - & - & - & - & - & - & - \\
\hline 17 & - & - & - & - & - & - & - & - & - & - & - & - & +++ & - \\
\hline 18 & - & - & - & - & - & - & - & - & - & - & - & - & - & - \\
\hline 19 & - & - & - & - & - & - & - & - & - & - & - & - & - & - \\
\hline 20 & - & - & - & - & - & - & - & - & - & - & - & - & - & - \\
\hline 21 & - & - & - & - & - & - & - & - & - & - & - & - & ++- & - \\
\hline 22 & - & - & - & - & - & - & - & - & - & - & - & - & - & - \\
\hline 23 & - & - & - & - & - & - & - & - & - & - & - & - & +++ & - \\
\hline 24 & - & - & - & - & - & - & - & - & - & - & - & - & - & - \\
\hline 25 & - & - & - & - & - & - & - & - & - & - & - & - & - & - \\
\hline 26 & - & - & - & - & - & - & - & - & - & - & - & - & - & - \\
\hline 27 & - & - & - & - & - & - & - & - & - & - & - & - & - & - \\
\hline 28 & - & - & - & - & - & - & - & - & - & - & - & - & - & - \\
\hline 29 & - & - & - & - & - & - & - & - & - & - & - & - & - & - \\
\hline 30 & - & - & - & - & - & - & - & - & - & - & - & - & ++- & - \\
\hline 31 & - & - & - & - & - & - & - & - & - & - & - & - & - & - \\
\hline 32 & - & - & - & - & - & - & - & - & - & - & - & - & - & - \\
\hline 33 & - & - & - & - & - & - & - & - & - & - & - & - & - & - \\
\hline 34 & - & - & - & - & - & - & - & - & - & - & - & - & +-- & - \\
\hline 35 & - & - & - & - & - & - & - & - & - & - & - & - & - & - \\
\hline 36 & - & - & - & - & - & - & - & - & - & - & - & - & - & - \\
\hline 37 & - & - & - & - & - & - & - & - & - & - & - & - & - & - \\
\hline
\end{tabular}

EP: Eco-Phage, $+++, 10^{-2}, 10^{-4}$ and $10^{-6}$ diluted phage samples were inhibitor positive; ++-, $10^{-2}, 10^{-4}$ diluted phage samples were inhibitor positive but $10^{-6}$ dilution sample was inhibitor negative; +--, $10^{-2}$ dilution sample was inhibitor positive, $10^{-4}$ and $10^{-6}$ dilution sample was inhibitor negative; -, $10^{-}$ ${ }^{2}, 10^{-4}$ and $10^{-6}$ diluted phage samples were inhibitor negative

\section{Conclusion}

Thirty seven bacteriophages specific to $E$. coli O157:H7 were isolated from sewage and wastewaters of food processing, slaughterhouse and fisheries, stream and trough using spot agar test against 5 different $E$. coli O157:H7 strains. Phages specific to E. coli $\mathrm{O} 157: \mathrm{H} 7$ strains with wide host range and lytic activity were mainly isolated from wastewater from food processing and slaughterhouse, sewage and troughs. These E. coli O157:H7 specific phages have broad host ranges and were able to lyse 1 to 8 of 36 strains tested and 15 out of 
37 Eco-phages $(40.54 \%)$ were infective against other $E$. coli strains tested. Additionally, 8 out of 37 isolated $E$. coli $\mathrm{O} 157: \mathrm{H} 7$ specific phages were capable to lyse some Salmonella enterica serovars.

These E. coli O157:H7 specific phages can be used as a possible alternative to chemical antimicrobials against foodborne pathogenic bacterium E. coli $\mathrm{O} 157: \mathrm{H} 7$ and can be use as therapeutic agents against animal infections caused by E. coli O157:H7.

\section{Acknowledgments}

This research was a part of project supported by the Scientific and Technological Research Council of Turkey (TUBITAK) (Project No: 2130035).

\section{References}

Adams MH 1959. Bacteriophages. New York: Interscience Publishers, Inc.

Akhtar M, Viazis S, Diez-Gonzalez F 2014. Isolation, identification and characterization of lytic, wide host range bacteriophages from waste effluents against Salmonella enterica serovars. Food Control 38: 67-74.

Bach SJ, McAllister TA, Veira DM, Gannon VPJ, Holley RA. 2003. Effect of bacteriophage DC22 on Escherichia coli O157:H7 in an artificial rumen system (Rusitec) and inoculated sheep. Animal Research, 52: 89-101.

Bhunia AK 2007. Esherichia coli. In: Foodborne Microbial Pathogens: Mechanisms and pathogenesis, Bhunia, A.K. (ed.), pp.183-200, Springer LLC, New York, NY.

Bielke LR, Higgins SE, Donoghue AM, Donoghue DJ, Hargis BM, Tellez G. 2007. Use of wide-host-range bacteriophages to reduce Salmonella on poultry products. International Journal of Poultry Science, 6: 754-757

Callaway TR, Edrington TS, Brabban AD, Anderson RC, Rossman ML, Engler MJ, Carr MA, Genovese KJ et al. 2008. Bacteriophage isolated from feedlot cattle can reduce Escherichia coli O157: H7 populations in ruminant gastrointestinal tracts. Food Pathogens Disease, 5: 183-191.

Carlton RM, Noordman WH, Biswas B, de Meester ED, Loessner MJ 2005. Bacteriophage P100 for control of Listeria monocytogenes in foods: genome sequence, bioinformatic analyses, oral toxicity study, and application. Regulatory Toxicology and Pharmacology, 43: 301-312.

CDC, 2011. Investigation update: outbreak of Shiga toxinproducing E. coli O104 (STEC O104:H4) infections associated with travel to Germany. Centers for Disease Control and Prevention, Atlanta, GA. http://www.cdc.gov/ecoli/2011/ecolio104/.

FDA, 2006. Food additives permitted for direct addition to food for human consumption; bacteriophage preparation. Federal Registration, 71: 47729-47732.

Hagens S, Loessner MJ 2014. Phages of Listeria offer novel tools for diagnostics and biocontrol. Frontiers Microbiology, 5: 159. DOI: $10.3389 /$ fmicb. 2014.00159

Ibrahim AAE. 1969. Bacteriophage typing of Salmonella I. Isolation and host range study of bacteriophages. Applied and Microbiology, 18: 444-447.

Kocharunchitt C, Ross T, McNeil DL. 2009. Use of bacteriophages as biocontrol agents to control Salmonella associated with seed sprouts. International Journal of Food Microbiology 128: 453-459.

Kudva IT, Jelacic S, Tarr PI, Youderian P, Hovde CJ. 1999. Biocontrol of Escherichia coli 0157 with O157-specific bacteriophages. Applied Environmental and Microbiology, 65: 3767-3773.
Litt PK, Jaroni D. 2017. Isolation and physiomorphological characterization of Escherichia coli O157:H7-infecting bacteriophages recovered from beef cattle operations. International Journal of Microbiology, Article ID 7013236, 12 pages.

Lu Z, Breidt F. 2015. Escherichia coli O157:H7 bacteriophage 241 isolated from an industrial cucumber fermentation at high acidity and salinity. Frontiers in Microbiology, 6:1-10.

McLaughlin MR, Balaa MF, Sims J, King R. 2006. Isolation of Salmonella bacteriophages from swine effluent lagoons. Journal of Environmental Quality, 35: 522-528.

Morita M, Tanji Y, Mizoguchi K, Akitsu T, Kijima N, Unno H. 2002. Characterization of a virulent bacteriophage specific for Escherichia coli $\mathrm{O} 157: \mathrm{H} 7$ and analysis of its cellular receptor and two tail fiber genes. FEMS Microbiology Letters, 211:77-83.

Niu Y, McAllister T, Xu Y, Johnson RP, Stephens TP, Stanford K. 2009. Prevalence and impact of bacteriophages on the presence of Escherichia coli O157: $\mathrm{H} 7$ in feedlot cattle and their environment. Applied and Environmental Microbiology, 75: 1271-1278.

Oot R, Raya R, Callaway T, Edrington TS, Kutter EM, Brabban AD. 2007. Prevalence of Escherichia coli O157 and O157: H7-infecting bacteriophages in feedlot cattle feces. Letters in Applied Microbiology, 45: 445-453.

Ray B. 2005. Fundamental Food Microbiology. CRC Press New York Washington, D.C.

Raya RR, Varey P, Oot RA, Dyen MR, Callaway TR, Edrington TS, Kutter EM, Brabban AD. 2006. Isolation and characterization of a new T-even bacteriophage, CEV1, and determination of its potential to reduce Escherichia coli O157:H7 levels in sheep. Applied and Environmental Microbiology, 72, 6405-6410.

Raya RR, Oot RA, Moore-Maley B, Wieland S, Callaway TR., et al. 2011. Naturally resident and exogenously applied T4like and T5-like bacteriophages can reduce Escherichia coli O157:H7 levels in sheep guts. Bacteriophage, 1:15-24.

Sartz L, De Jong, B, Hjertqvist M, Plym-Forshell L, Alsterlund R, Löfdahl S, Osterman B, Ståhl A, Eriksson E, Hansson HB, Karpman D. 2008. An outbreak of Escherichia coli O157:H7 infection in southern Sweden associated with consumption of fermented sausage; aspects of sausage production that increase the risk of contamination. Epidemiological Infection, 136: 370-380.

Sheng H, Knecht HJ, Kudva IT, Hovde CJ. 2006. Application of bacteriophages to control intestinal Escherichia coli O157:H7 levels in ruminants. Applied and Environmental Microbiology, 72: 5359-5366.

Stenholm AR, Dalsgaard I, Middelboe M. 2008. Isolation and characterization of bacteriophages infecting the fish pathogen Flavobacterium psychrophilum. Applied and Environmental Microbiolgy, 74: 4070-4078.

Synnott AJ, Kuang Y, Kurimoto M, Yamamichi K, Iwano H, Tanji Y. 2009. Isolation from sewage influent and characterization of novel Staphylococcus aureus bacteriophages with wide host ranges and potent lytic capabilities. Applied and Environmental Microbiology, 75: 4483-4490.

Tarr PI, Gordon CA, Chandler WL. 2005. Shiga-toxinproducing Escherichia coli and haemolytic uraemic syndrome. Lancet 365: 1073-1086.

Tolba MH, Meshref AMS, Zeinhom MMA. 2014. Biocontrol of Escherichia coli O126:H7 in skim milk using bacteriophages. American Journal of Animal and Veterinary Sciences, 9: 221-229.

Viazis S, Akhtar M, Feirtag J, Brabban AD, Diez-Gonzalez F. 2011. Isolation and characterization of lytic bacteriophages against enterohaemorrhagic Escherichia coli. Journal of Applied Microbiology, 110: 1323-31. 
Villegas A, She YM, Kropinski AM, Lingohr EJ, Mazzocco A, Ojha S, Waddell TE, Ackermann HW, Moyles DM, Ahmed R, Johnson RP. 2009. The genome and proteome of a virulent Escherichia coli O157:H7 bacteriophage closely resembling Salmonella phage FelixO1. Virology Journal 6: 41
Wu CJ, Hsueh PR, Ko WC. 2011. A new health threat in Europe: Shiga toxin producing Escherichia coli $\mathrm{O} 104: \mathrm{H} 4$ infections. Journal of Microbiology, Immunology and Infection 44: 390-393. 